\title{
Endoscopic Palliation for Biliary and Pancreatic Malignancies: Recent Advances
}

\author{
Zaheer Nabi and D. Nageshwar Reddy \\ Asian Institute of Gastroenterology, Hyderabad, India
}

Malignancies of the pancreatobiliary system are usually unresectable at the time of diagnosis. As a consequence, a majority of these cases are candidates for palliative care. With advances in chemotherapeutic agents and multidisciplinary care, the survival rate in pancreatobiliary malignancies has improved. Therefore, there is a need to provide an effective and long-lasting palliative care for these patients. Endoscopic palliation is preferred to surgery as the former is associated with equal efficacy and reduced morbidity. The main role of endoscopic palliation in the vast majority of pancreatobiliary malignancies includes biliary and enteral stenting for malignant obstructive jaundice and gastric outlet obstruction, respectively. Recent advances in endoscopic palliation appear promising in imparting long-lasting relief of symptoms. Use of radiofrequency ablation and photodynamic therapy in malignant biliary obstruction has been shown to improve the survival rates as well as the patency of biliary stents. The emergence of endoscopic ultrasound (EUS) as a therapeutic tool has enhanced the capability of minimally invasive palliation in pancreatobiliary cancers. EUS is a valuable alternative to endoscopic retrograde cholangiopancreatography for the palliation of obstructive jaundice. More recently, EUS is emerging as an effective primary modality for biliary and gastric bypass. Clin Endosc 2019;52:226-234

Key Words: Pancreatic neoplasms; Palliation; Radiofrequency ablation; Endoscopic ultrasound

\section{INTRODUCTION}

Malignancies of the pancreas and biliary system are among the leading causes of gastrointestinal cancer-related mortality. The majority of pancreatobiliary malignancies are unresectable at the time of presentation. Therefore, palliation of symptoms including pain, jaundice, and pruritus is the main objective in these patients. Endoscopic palliation in these patients is minimally invasive and therefore associated with decreased morbidity compared to palliative surgery. With recent advances in systemic chemotherapy, survival rates have improved especially in pancreatic cancer. ${ }^{1}$ This means that palliation of

Received: November 22, 2018 Revised: December 17, 2018 Accepted: December 17, 2018

Correspondence: Zaheer Nab

Asian Institute of Gastroenterology, 6-3-661, Somajiguda, Hyderabad 500082, India

Tel: +91-40-2337-8888, Fax: +91-40-2332-4255, E-mail: zaheernabi1978@gmail.com ORCID: https://orcid.org/0000-0003-2713-4781

(cc) This is an Open Access article distributed under the terms of the Creative Commons Attribution Non-Commercial License (http://creativecommons.org/ licenses/by-nc/3.0) which permits unrestricted non-commercial use, distribution, and reproduction in any medium, provided the original work is properly cited. symptoms should not only be effective, but also long-lasting to avoid morbidity-related repeated interventions. Endoscopic palliation in pancreatobiliary malignancies include biliary drainage, enteral stenting for gastric outlet obstruction, and celiac plexus neurolysis for relief of pain.

Over the last decade, the role of endoscopy as a palliative modality has broadened with the availability of novel tools and techniques. The development of endoscopic ultrasound (EUS) as a therapeutic modality has allowed a wide array of remedial procedures to be performed endoscopically.

\section{ENDOSCOPIC PALLIATION OF MALIGNANT BILIARY OBSTRUCTION}

A large proportion of cases with malignant biliary obstruction $(\mathrm{MBO})$ are unresectable at the time of presentation. The aim of palliation in these patients is to improve the quality of life by reducing jaundice and pruritus. Endoscopic palliation is preferred over surgery as the former is associated with reduced morbidity and equal benefits. Self-expandable metal 
stents (SEMS) are preferred over plastic stents for endoscopic palliation of patients with MBO. The use of SEMS results in longer stent patency, lower complication rates, fewer re-interventions, and possibly increased survival rates. ${ }^{2}$ In addition, SEMS placement results in better scores for general and disease-specific health related quality of life compared with plastic stent placement. ${ }^{3}$ Although SEMS are more expensive than plastic stents, there is no significant cost difference in the long term due to reduced requirements for re-interventions. ${ }^{4}$ The choice of SEMS (covered or uncovered) is largely operator-dependent as there is no significant difference with regard to the clinical outcomes. ${ }^{5}$ Covered SEMS have lower tissue ingrowth, but higher migration rates and tissue overgrowth as compared to uncovered SEMS.

The main issue with biliary drainage using stents is re-occlusion. In order to prolong stent patency, various strategies have been evaluated including incorporation of chemotherapeutic agents into the covering material of stents and ablating the tumor using radiofrequency ablation (RFA) prior to stent deployment. Drug-eluting stents were evaluated in animal and small cohort human studies with the hope of reducing stent dysfunction due to tumor ingrowth. ${ }^{6-10}$ Although there were no major safety issues, the outcomes were sub-optimal with regard to the improvement in stent patency. More recently, a vorinostat-eluting poly (DL-lactide-co-glycolide) nanofiber-coated stent was evaluated for the inhibition of cholangiocarcinoma cells. Vorinostat is a histone deacetylase inhibitor with inhibitory effects on growth and differentiation of malignant cells. Vorinostat-eluting nanofiber membranes showed significant antitumor activity against cholangiocarcinoma cells in vitro and in vivo. ${ }^{11}$ Large, prospective trials are required to evaluate the clinical utility of novel drug-eluting stents in patients with $\mathrm{MBO}$.

\section{ENDOSCOPIC ULTRASOUND GUIDED BILIARY DRAINAGE}

EUS has emerged as an immensely useful therapeutic modality for palliation in pancreatobiliary malignancies. Combined biliary and gastric outlet obstruction is not uncommon in advanced biliary and pancreatic neoplasms. In these cases, papilla may not be accessible and therefore endoscopic palliation of biliary obstruction with endoscopic retrograde cholangiopancreatography (ERCP) is often not feasible. On the other hand, biliary cannulation is occasionally unsuccessful due to neoplastic infiltration of the papilla or surgically-altered anatomy. Palliation of jaundice can be successfully accomplished using EUS guided approaches in such cases. When compared to percutaneous drainage, EUS-guided biliary drainage (EUS$\mathrm{BD}$ ) is equally effective, but associated with a lower rate of adverse events and fewer re-interventions. ${ }^{12,13}$ Until recently, EUS-BD was used as a rescue option in patients with failed ERCPs. Experts in EUS have challenged this approach and utilized EUS-BD as a primary method for biliary drainage. Three randomized trials have compared EUS with ERCP as a primary modality for biliary drainage in cases with $\mathrm{MBO}$ (Table 1). ${ }^{14-16}$ Clinical outcomes in terms of clinical success and adverse events were equal in two trials, ${ }^{14,16}$ whereas EUS-BD was found to be superior to ERCP with longer stent patency, lower adverse events, and fewer re-interventions in one of the randomized trials. ${ }^{15}$ With the development of dedicated

Table 1. Randomized Controlled Trials of Endoscopic Ultrasound vs. Endoscopic Retrograde Cholangiopancreatography for Biliary Drainage

\begin{tabular}{|c|c|c|c|c|c|c|}
\hline Study & $n$ & EUS-BD & $\begin{array}{l}\text { Technical suc- } \\
\text { cess }\end{array}$ & $\begin{array}{l}\text { Clinical } \\
\text { success }\end{array}$ & $\begin{array}{l}\text { Adverse events/ } \\
\text { Re-intervention }\end{array}$ & Stent patency \\
\hline $\begin{array}{l}\text { Paik et al. } \\
(2018)^{15}\end{array}$ & $\begin{array}{c}125 \\
\text { EUS-BD: } 64 \\
\text { ERCP: } 61 \\
\text { (62.4\% pancreatic } \\
\text { malignancies) }\end{array}$ & $\begin{array}{l}\text { CDS } 32 \\
\text { HGS } 32\end{array}$ & $93.8 \%$ vs. $90.2 \%$ & $90 \%$ vs. $94.5 \%$ & $\begin{array}{c}6.3 \% \text { vs. } 19.7 \% \\
22.2 \% \text { vs. } 46.7 \%\end{array}$ & $\begin{array}{c}85.1 \% \text { vs. } 48.9 \% \\
\text { at } 6 \text { mo } \\
\text { Median: } 208 \text { days vs. } \\
165 \text { days }\end{array}$ \\
\hline $\begin{array}{l}\text { Bang et al. } \\
(2018)^{16}\end{array}$ & $\begin{array}{c}67 \\
\text { EUS-BD: } 33 \\
\text { ERCP: } 34 \\
\text { (all pancreatic) }\end{array}$ & CDS & $90.9 \%$ vs. $94.1 \%$ & $97 \%$ vs. $91.2 \%$ & $\begin{array}{c}21.2 \% \text { vs. } 14.7 \% \\
3.0 \% \text { vs. } 2.9 \%\end{array}$ & 182 days vs. 170 days \\
\hline $\begin{array}{l}\text { Park et al. } \\
\qquad(2018)^{14}\end{array}$ & $\begin{array}{c}30 \\
\text { EUS-BD: } 15 \\
\text { ERCP: } 15 \\
\text { (90\% pancreatic) }\end{array}$ & CDS & $93 \%$ vs. $100 \%$ & $100 \%$ vs. $93 \%$ & $\begin{array}{c}15.4 \% \text { vs. } 30.8 \% \\
\text { (stent dysfunction) }\end{array}$ & 379 days vs. 403 days \\
\hline
\end{tabular}

CDS, choledochoduodenostomy; ERCP, endoscopic retrograde cholangiopancreatography; EUS-BD, endoscopic ultrasound-guided biliary drainage; HGS, hepaticogastrostomy. 
devices and accessories, EUS-BD is likely to become a useful alternative to ERCP in MBO.

\section{ENDOSCOPIC ABLATION IN PANCREATOBILIARY NEOPLASMS}

\section{Malignant biliary obstruction}

RFA and photodynamic therapy (PDT) are the main palliative modalities for unresectable cholangiocarcinoma. RFA is a thermal ablative tool based on the principle that heat causes coagulative necrosis and reduction in tumor volume. Recently, RFA is being increasingly utilized for the palliation of unresectable pancreatobiliary malignancies (Table 2) ${ }^{17}$ Steel et al., reported the first human application of RFA in 21 cases with $\mathrm{MBO}^{18}$ At 90 days, stent patency was documented in 16 of 21 patients. ${ }^{18}$ Since this seminal study, the body of evidence is growing for the utility of RFA in MBO where it has been shown to prolong the patency of SEMS as well as improve the survival rates (Table 3). ${ }^{18-28}$ In a randomized study by Yang and colleagues, 65 patients with extrahepatic cholangiocarcinoma were randomized into stent only and RFA+ stent groups. ${ }^{28}$ The mean stent patency period of the RFA+ stent group was significantly longer than that of the stent-only group (6.8 months vs. 3.4 months, $p=0.02$ ). ${ }^{28}$ In addition to improved stent paten$\mathrm{cy}$, a few studies have also documented a survival benefit with adjunctive RFA. ${ }^{21,22,28}$ In a randomized trial, the mean survival was significantly longer in the RFA+ stent group than in the stent-only group (13.2 +/- 0.6 months vs. $8.3+/-0.5$ months, $p<0.001) .{ }^{28}$ In a systematic review and metanalysis including nine studies (505 patients), the pooled weighted mean difference in the stent patency was 50.6 days in favor of RFA. Overall survival was also better in patients treated with RFA (hazard ratio, 1.395; 95\% confidence interval, $1.145-1.7 ; p<0.001){ }^{27}$

The possible actions of RFA include opening up biliary strictures by debulking and preventing the proximal spread of tumor. In a recent study, the mean stricture diameter was 1.7 $\mathrm{mm}$ and $5.2 \mathrm{~mm}$ before and after endoscopic RFA, respectively. ${ }^{19}$ In addition to local ablation, RFA also incites an immune response towards malignant cells and could be the possible reason for improved survival in these patients. ${ }^{27}$

Adverse events with biliary RFA include abdominal pain, cholangitis, hemobilia, and cholecystitis. In addition, serious adverse events like partial liver infarction due to vascular injury have been reported after RFA. ${ }^{20}$ The proximity of the proximal biliary tract to the hepatic artery may be responsible for such vascular events. It is important to note that some of these adverse events may not be related to RFA per se. For example, cholecystitis after SEMS placement, with or without preceding RFA, is mainly attributable to tumor involvement of the cystic duct. In a systematic review, abdominal pain was higher in the RFA group ( $31 \%$ vs. $20 \%, p=0.003$ ). However, there was no significant difference between the RFA and stent-only groups with regard to cholangitis, acute cholecystitis, pancreatitis, and hemobilia. ${ }^{27}$

The other palliative modality for cholangiocarcinoma with promising results in recent studies is PDT. ${ }^{29-32}$ In an early randomized trial by Ortner and colleagues, PDT resulted in better biliary drainage and improved survival in patients with non-resectable cholangiocarcinoma (493 days vs. 98 days, $p<0.0001) .{ }^{32}$ In a systematic review and meta-analysis, PDT was superior to biliary stenting alone with regard to successful biliary drainage ( $>50 \%$ reduction in bilirubin at day 7$)$ and survival. ${ }^{33}$ In contrast to the favorable outcomes in a majority of the studies, a recent randomized trial concluded that overall survival was worse in the PDT group as compared to the stent-alone group. ${ }^{34}$ The results of this study should be interpreted with caution as there was a difference in the chemotherapy regimens in the two groups.

In a retrospective comparative study by Strand and colleagues, survival rates were similar between RFA and PDT (9.6 months vs. 7.5 months). ${ }^{35}$ However, a randomized trial is required to compare both these modalities. PDT is safe and major adverse events are uncommon. Self-limiting photosensitivity reactions can be seen in about $10 \%$ of the patients. ${ }^{33}$

\section{Pancreatic neoplasms}

Endoscopic ablation has also been successfully used for the

Table 2. Radiofrequency Ablation Devices for Biliopancreatic Use ${ }^{17}$

\begin{tabular}{lccc}
\hline System or catheter & $\begin{array}{c}\text { Catheter } \\
\text { diameter }\end{array}$ & Length & $\begin{array}{c}\text { Electrode dimensions } \\
\text { (length } \times \text { diameter) }\end{array}$ \\
\hline Habib EUS-RFA & $1 \mathrm{~F}$ & $220 \mathrm{~cm}$ & $20 \mathrm{~mm} \times 1 \mathrm{~F}$ \\
Habib Endo HPB & $8 \mathrm{~F}$ & $200 \mathrm{~cm}$ & $8 \mathrm{~mm} \times 8 \mathrm{~F}(2 \mathrm{electrodes})$ \\
$\begin{array}{l}\text { EUSRA } \\
\text { Electrode }\end{array}$ & $18 \mathrm{G}$ & $150 \mathrm{~cm}$ & $7 \mathrm{~mm} \times 18 \mathrm{G}$ \\
ELRA $^{\mathrm{TM}}$ endobiliary RFA & $7 \mathrm{~F}$ & $175 \mathrm{~cm}$ & 18 and $33 \mathrm{~mm} \times 7 \mathrm{~F}$ \\
\hline
\end{tabular}

EUS-RFA, endoscopic ultrasound-guided radiofrequency ablation. 
palliation of solid/cystic pancreatic neoplasms and for treating intraductal extension of ampullary neoplasms. ${ }^{36-42}$ EUS-guided ablation was initially reported for cystic neoplasms of the pancreas in multiple small studies. Absolute alcohol (80\%) as well as chemotherapeutic agents like gemcitabine and paclitaxel have been used as ablative agents in various studies. ${ }^{43,44}$ One large study involving 164 cases, evaluated the long-term outcomes of endoscopic ablation in patients with pancreatic cysts. $^{44}$ A majority of these cystic lesions were either mucinous cystic neoplasms (43\%) or indeterminate cysts (38\%). At a median follow-up of 72 months, complete or partial resolution of cysts was noticed in $72.2 \%$ and $19.6 \%$ of cases, respectively. Of those with complete resolution, recurrence was found in only 2 patients (1.7\%). ${ }^{44}$ Encouraging results of EUS-guided ablation in cystic neoplasms propelled the evaluation of endoscopic ablation in solid pancreatic tumors including neuroendocrine tumors and unresectable adenocarcinomas. ${ }^{38,41,42,45}$

A majority of the patients with pancreatic cancer have locally advanced or metastatic disease at the time of presentation. The survival rate is poor in these cases and chemora- diotherapy provides only marginal benefits. Therefore, there is an unmet need for palliative modalities in this subgroup of patients. Intra-operative RFA has been shown to improve survival rates in stage III and IV pancreatic cancers. ${ }^{46,47}$ In one study, intra-operative RFA in combination with palliative surgery resulted in significantly better survival rates than palliative surgery alone in patients with advanced pancreatic cancers. ${ }^{46}$ In contrast to intra-operative RFA, EUS is minimally invasive and carries the ability to visualize and accurately target deep-seated pancreatic lesions in real time. Goldberg and colleagues demonstrated the feasibility and safety of EUSRFA in thirteen Yorkshire pigs. ${ }^{48}$ A $19 \mathrm{G}$ needle was used for ablation which was insulated except for the distal 1 to 1.5 $\mathrm{cm}$. For each ablation, RF was applied for 6 minutes and the electrode tip temperature of $90^{\circ} \pm 2^{\circ} \mathrm{C}$ was maintained. Hyperechoic foci measuring about $1 \mathrm{~cm}$ and representing the area of coagulation necrosis were observed after RFA. Complications included focal pancreatitis in one, intestinal burn in one, and gastric burns in three pigs. ${ }^{48}$ Subsequently, several small cohort human studies have evaluated the technical fea-

Table 3. Radiofrequency Ablation for Malignant Biliary Obstruction

\begin{tabular}{|c|c|c|c|c|c|}
\hline Study & $n$ & Malignancy & $\begin{array}{c}\text { Mean/Median stent } \\
\text { patency }\end{array}$ & Mean/Median survival & Adverse events \\
\hline Steel et al. $(2011)^{18}$ & 22 & $\begin{array}{l}\text { (73\% pancreatic, } \\
27 \% \text { CCA })\end{array}$ & 114 (0-498) days & 90-day: $76.2 \%$ & $19 \%$ \\
\hline $\begin{array}{l}\text { Figueroa-Barojas et al. } \\
(2013)^{19}\end{array}$ & 20 & $\begin{array}{l}\text { CCA } 11 \\
\text { Pancreatic Ca } 7 \\
\text { IPMN } 1 \\
\text { Gastric Ca } 1\end{array}$ & N/A & N/A & $35 \%$ \\
\hline Dolak et al. $(2014)^{20}$ & $\begin{array}{c}58 \\
\text { (84 sessions) }\end{array}$ & $\begin{array}{l}\text { Majority Klatskin } \\
(77.6 \%)\end{array}$ & 170 days & $10.6 \mathrm{mo}$ & $\begin{array}{c}14.3 \% \\
\text { (12/84 RFA sessions) }\end{array}$ \\
\hline Sharaiha et al. $(2014)^{21}$ & 64 (RFA 26) & $\begin{array}{l}\text { Pancreatic Ca } 28 \\
\text { CCA } 36\end{array}$ & N/A & $5.9 \mathrm{mo}$ & $7.7 \%$ \\
\hline Kallis et al. $(2015)^{22}$ & 23 & Pancreatic Ca & 472 days & 226 days & N/A \\
\hline Liang et al. $(2015)^{23}$ & 76 (34 RFA) & All CCA & $9.5(4.5-14) \mathrm{mo}$ & $\mathrm{N} / \mathrm{A}$ & $26.5 \%$ \\
\hline Hu et al. $(2016)^{24}$ & $\begin{array}{c}63 \\
\text { RFA } 32 \\
\text { Stenting } 31\end{array}$ & $\begin{array}{l}\text { Hilar CCA } 19 \\
\text { Mid CBD } 35 \\
\text { Ampullary } 9\end{array}$ & $\begin{array}{l}150 \text { days } \\
117 \text { days }\end{array}$ & $\begin{array}{l}311 \text { days } \\
172 \text { days }\end{array}$ & N/A \\
\hline Laquière et al. $(2016)^{25}$ & 12 & $\begin{array}{l}\text { Bismuth I/ II } 7 \\
\text { III/IV } 5\end{array}$ & N/A & $12.3 \mathrm{mo}(3-32)$ & $16.7 \%$ \\
\hline Wang et al. $(2016)^{26}$ & $\begin{array}{c}12 \\
\text { (20 RFA } \\
\text { sessions) }\end{array}$ & $\begin{array}{l}\text { CCA } 9 \\
\text { Liver Ca } 1 \\
\text { Gastric Ca } 1 \\
\text { Choledochal cyst } 1\end{array}$ & 125 days & 232 days & $\begin{array}{l}\text { Fever- } 2 \\
\text { PEP- } 1\end{array}$ \\
\hline Yang $(2018)^{28}$ & $\begin{array}{c}65 \\
\text { RFA+ stent } 32 \\
\text { Stent only } 33\end{array}$ & Extrahepatic CCA & $\begin{array}{c}6.8 \mathrm{mo} \text { vs. } 3.4 \mathrm{mo} \\
(p=0.02)\end{array}$ & $\begin{array}{c}13.2 \pm 0.6 \text { vs. } 8.3 \pm 0.5 \\
(p<0.001)\end{array}$ & $6.3 \%$ vs. $9.1 \%$ \\
\hline
\end{tabular}

Ca, carcinoma; CBD, common bile duct; CCA, cholangiocarcinoma; IPMN, intraductal papillary mucinous neoplasm; N/A, not available; PEP, post endoscopic retrograde cholangiopancreatography pancreatitis; RFA, radiofrequency ablation. 
sibility and safety of EUS-RFA in pancreatic neoplasms (Table 4) ${ }^{38,41,42}$ In a small study including 6 patients with stage III and IV pancreatic cancers, EUS-RFA was technically feasible in all the cases without any major complications. ${ }^{38}$ However, most of these studies are small and depict only the safety and feasibility of RFA in these patients. The actual clinical benefit in terms of improvement in survival rates remains to be seen. Adverse events reported with EUS-RFA include abdominal pain, acute pancreatitis, pancreatic fistulas, and portal vein thrombosis. ${ }^{45,47}$ The risk of pancreatitis appears to be higher when lesions are located in the pancreatic head and in close proximity to the main pancreatic duct $(<5 \mathrm{~mm})$. Placement of a prophylactic pancreatic stent and keeping a safety margin ( $>5 \mathrm{~mm}$ from pancreatic duct) have been suggested as ways to reduce the risk of pancreatitis. ${ }^{45}$ Another strategy to reduce complications includes decreasing the RFA temperature from $105^{\circ}$ to $90^{\circ} \mathrm{C} .{ }^{47}$ Recently, new cryothermal probes, which are internally cooled with carbon dioxide, have been evaluated in animal studies. ${ }^{49,50}$ The cryogenic gas produces effective cooling and therefore less collateral damage is expected. In addition, it augments the devitalization such that less power input (16 W) is needed compared with conventional RF ablation systems $(30-60 \mathrm{~W})$, to obtain the same ablation results. ${ }^{49}$ The safety of these probes over conventional ablation probes and their application in humans remains to be demonstrated.

Besides RFA, the use of EUS-guided laser (Nd:YAG) ablation and PDT has been described for ablating pancreatic tissue. ${ }^{51-54}$ Di Matteo and colleagues initially demonstrated the feasibility of pancreatic laser ablation in a couple of animal studies. ${ }^{52,53}$ Subsequently, the same group evaluated the outcomes of laser ablation in nine patients with locally advanced pancreatic cancers (mean size $35.4 \mathrm{~mm}$ ) that did not respond to chemoradiotherapy. ${ }^{51}$ A $300-\mu \mathrm{m}$ flexible fiber (Elesta s.r.l., Florence, Italy) preloaded onto a $22 \mathrm{G}$ fine needle was used for laser ablation. The power settings were $2-4 \mathrm{~W} / 400-1,200 \mathrm{~J}$ and the ablation time ranged from 200-600 seconds. The ablation was completed for all patients with an ablation area of $0.4-6.4 \mathrm{~cm}^{3}$. There were no major adverse events. ${ }^{51}$

Endoscopic-RFA has also been successfully used for ampullary adenomas with intraductal extensions. ${ }^{37,39,40}$ These patients are often managed using Whipple's surgery which has a high morbidity rate. In a series of 14 patients with adenoma extension into the common bile duct, RFA was successfully performed in 13 patients. Of these, surveillance-intraductal biopsy specimens showed no neoplasm in 12 patients. The main adverse event was ductal stricture in 5 patients. ${ }^{39}$

\section{Others}

Other applications of EUS in pancreatobiliary malignancies include control of pain, placement of fiducial markers for image-guided radiotherapy, and delivery of antitumor agents into the tumor.

Pain is often a troubling symptom in patients with pancreatic cancer. Celiac-plexus neurolysis is recommended, but the effect is short-lived. Recently, RFA has been utilized for ablation of celiac ganglia in these patients. ${ }^{55,56}$ Bang and colleagues compared EUS-RFA to traditional celiac-plexus neurolysis in a randomized trial. ${ }^{55}$ The Habib EUS-RFA catheter (EMcision Ltd., London, United Kingdom) and a $19 \mathrm{G}$ needle were used for ablation in this study. A total of 2 to 4 RFA applications (90 seconds, $10 \mathrm{~W}$ ) were used. EUS-RFA provided better pain relief without any difference in the rate of adverse events. Importantly, $21 \%$ of patients with persistent pain after celiac-plexus neurolysis could be successfully managed with RFA.

Table 4. Endoscopic Ablation in Unresectable Pancreatic Cancers

\begin{tabular}{|c|c|c|c|c|c|}
\hline Study & $n$ & Equipment & Tumor diameter $(\mathrm{cm})$ & Ablation area & Adverse events \\
\hline $\begin{array}{l}\text { Arcidiacono et al. } \\
(2012)^{36}\end{array}$ & 22 & $\begin{array}{l}\text { Cryotherm probe, } \\
\text { VIO 300D RF-surgery system, } \\
18 \mathrm{~W}\end{array}$ & $3.6(2.3-5.4)$ & $\mathrm{N} / \mathrm{A}$ & $\begin{array}{l}\text { Pain- } 3 \\
\text { Bleeding- } 1 \\
\text { Jaundice- } 2 \\
\text { Duodenal stricture- } 1 \\
\text { Cystic fluid collection- } 1\end{array}$ \\
\hline Song et al. $(2016)^{38}$ & 6 & $\begin{array}{l}18 \text { G needle, VIVA RF generator } \\
\text { (STARmed, Koyang, Korea), } 10 \text { W }\end{array}$ & 3.8 (range, 3-9) & N/A & $\begin{array}{l}\text { Mild abdominal pain in } \\
2 \text { pts }\end{array}$ \\
\hline Scopelliti et al. $(2018)^{41}$ & 10 & $\begin{array}{l}\text { monopolar 18-gauge electrode, } \\
\text { EUSRA -STARMED, 20-30 W }\end{array}$ & $3.5-7.5$ & $\begin{array}{l}1.7-5.7 \mathrm{~cm} \\
\text { (at } 7 \text { days) }\end{array}$ & Abdominal pain in $2 \mathrm{pts}$ \\
\hline Crinò et al. $(2018)^{42}$ & $9(8)$ & $\begin{array}{l}\text { 18-gauge EUSRA electrode needle, } \\
\text { VIVA RF generator, } 30 \mathrm{~W}\end{array}$ & 3.6 (range, 2.2-6.7) & $\begin{array}{c}3.75 \mathrm{~cm}^{3} \\
(0.72-12.6)\end{array}$ & $\begin{array}{l}\text { Mild abdominal pain in } \\
3 \text { pts }\end{array}$ \\
\hline $\begin{array}{l}\text { Di Matteo et al. } \\
(2018)^{51}\end{array}$ & 9 & $\begin{array}{l}\text { Laser ablation, } 2-4 \mathrm{~W} / 400-1,000 \mathrm{~J} \\
300-\mu \mathrm{m} \text { flexible fiber, } 22 \mathrm{G} \text { needle }\end{array}$ & 3.5 (range, 2.1-4.5) & $0.4-6.4 \mathrm{~cm}^{3}$ & $\begin{array}{l}\text { Thin peripancreatic fluid } \\
\text { collection- } 3 \\
\text { Raised amylase- } 2\end{array}$ \\
\hline
\end{tabular}

N/A, not available. 
The proposed advantages of EUS-RFA over celiac-plexus neurolysis using alcohol include a predictable area of necrosis and immediate symptom relief. ${ }^{55}$ However, the data is limited and the ideal settings of RFA have yet to be determined in these patients.

Another emerging application of EUS in pancreatic neoplasms is the delivery of antitumor agents into the malignant tissue. Systemic chemotherapy is not very effective in pancreatic cancers partly due to the limited penetration of chemotherapeutic agents. Antitumor agents that have been evaluated for EUS-guided injection include gemcitabine, genetically-modified viruses (adenovirus: ONYX-015, TNFerade; herpes simplex virus: HF10), double-stranded RNA oligonucleotide (STNM01), double-stranded DNA plasmid (BC-819), dendritic cells, and cytoimplants. ${ }^{57-61}$ Preliminary data indicate the feasibility of EUS-guided injection of these agents. However, large scale studies are required to establish the safety and efficacy of endoscopic injection of antitumor agents in patients with advanced pancreatic cancer.

EUS-guided placement of inert radiopaque markers, i.e., fiducial markers into the tumor tissue, has been evaluated in patients with locally advanced pancreatic cancers. These markers serve as a guide for subsequent stereotactic body radiotherapy. Fiducial markers are available as radiopaque spheres or coils. Traditional fiducials are thicker $(0.8 \mathrm{~mm}$ diameter $)$ than coiled fiducials $\left(0.35 \mathrm{~mm}\right.$ diameter) and offer better visualization. ${ }^{62}$ However, a $19 \mathrm{G}$ needle is required for their deployment. Coiled fiducial markers (Visicoil; IBA Dosimetry, Bartlett, TN, USA) are thinner and can be deployed with a $22 \mathrm{G}$ needle which may have greater flexibility and access to the tumor. ${ }^{63}$ Multiple studies have confirmed the safety and feasibility of EUS-guided placement of fiducial markers. ${ }^{62-65}$ There are two main techniques for EUS-guided fiducial insertion. In one technique, once the needle is inserted into the target lesion, the fiducial is manually loaded and pushed with the help of a stylet or sterile water. In the second technique, the needle is pre-loaded with one or more fiducials and sealed with sterile bone wax. Subsequently, the fiducials can then be pushed using sterile water or saline. The main complication appears to be pancreatitis and spontaneous migration of markers necessitating a second EUS procedure. In addition, surgically-altered anatomy, such as a previous pancreaticoduodenectomy, may hinder successful placement of fiducial markers. There is no dedicated delivery system for the placement of fiducials under EUS-guidance. Recently, Draganov and colleagues evaluated a novel multi-fiducial delivery system in a porcine model. ${ }^{66} \mathrm{~A}$ prototype $22 \mathrm{G}$ needle pre-loaded with four fiducials was used in this study. Technical success in fiducial deployment was achieved in $96 \%$ of study animals and the time for placement of the four fiducials was $<1 \mathrm{~min}(0.86+/-0.50 \mathrm{~min}){ }^{66}$

\section{ENDOSCOPIC PALLIATION OF GASTRIC OUTLET OBSTRUCTION}

A substantial proportion of pancreatobiliary malignancies have concomitant gastric outlet obstruction due to tumor infiltration. Endoscopic placement of an enteral metal stent is usually effective in these cases and associated with less morbidity as compared to surgical bypass. ${ }^{67-69}$ Recently, EUS-guided gastro-enterostomy (EUS-GE) has been reported in patients with malignant gastric-outlet obstruction. ${ }^{70-72}$ EUS-GE has been compared with laparoscopic GE and enteral stenting. In a recent multicenter study, EUS-GE was equally efficacious with fewer adverse events as compared to laparoscopic $\mathrm{GE} .^{73}$ Similar conclusions were drawn in another study, where both the modalities were equal with respect to clinical success, adverse events, and recurrence of obstruction. ${ }^{74}$ EUS-GE and enteral stenting were found to have comparable safety and efficacy in one study, but EUS-GE was associated with fewer symptom recurrences and requirements for re-intervention. ${ }^{75}$ The stent is deployed away from the site of tumor infiltration with EUS-GE in contrast to enteral stenting. This may theoretically reduce the chances of stent dysfunction due to tumor ingrowth or overgrowth.

EUS-GE can be performed by three different techniques including: (a) direct EUS-GE, (b) assisted EUS-GE using retrieval/dilating balloons, single balloon overtube, nasobiliary drain, and ultraslim endoscope, and (c) EUS-guided double-balloon-occluded gastrojejunostomy bypass. ${ }^{76}$ In a recent multicenter study, direct and balloon assisted EUS-GE were compared in patients with gastric-outlet obstruction (2/3rd malignant). Technical and clinical success were similar in both the groups ( $>90 \%)$. However, the procedure duration was shorter with the direct technique $(35.7 \pm 32.1$ minutes vs. $89.9 \pm 33.3$ minutes, $p<0.001) .{ }^{77}$

\section{CONCLUSIONS}

Endoscopic palliation is preferred over surgery in a majority of the patients with unresectable pancreatobiliary malignancies. Recent advances in this field include endoscopic ablation in MBO, EUS-guided ablation of locally advanced pancreatic cancers, and the use of EUS for biliary and gastric bypass. These advances are in different phases of development and many of them are not yet ready for general implementation. With the development of dedicated devices and accessories, EUS is likely to play a bigger role in a wide range of palliative procedures in these patients. 


\section{Conflicts of Interest}

The authors have no financial conflicts of interest.

\section{REFERENCES}

1. Suker M, Beumer BR, Sadot E, et al. FOLFIRINOX for locally advanced pancreatic cancer: a systematic review and patient-level meta-analysis. Lancet Oncol 2016;17:801-810.

2. Almadi MA, Barkun A, Martel M. Plastic vs. self-expandable metal stents for palliation in malignant biliary obstruction: a series of meta-analyses. Am J Gastroenterol 2017;112:260-273.

3. Walter D, van Boeckel PG, Groenen MJ, et al. Higher quality of life after metal stent placement compared with plastic stent placement for malignant extrahepatic bile duct obstruction: a randomized controlled trial. Eur J Gastroenterol Hepatol 2017;29:231-237.

4. Walter D, van Boeckel PG, Groenen MJ, et al. Cost efficacy of metal stents for palliation of extrahepatic bile duct obstruction in a randomized controlled trial. Gastroenterology 2015;149:130-138.

5. Almadi MA, Barkun AN, Martel M. No benefit of covered vs uncovered self-expandable metal stents in patients with malignant distal biliary obstruction: a meta-analysis. Clin Gastroenterol Hepatol 2013;11:27-37. el.

6. Jang SI, Kim JH, You JW, et al. Efficacy of a metallic stent covered with a paclitaxel-incorporated membrane versus a covered metal stent for malignant biliary obstruction: a prospective comparative study. Dig Dis Sci 2013;58:865-871.

7. Jang SI, Lee SJ, Jeong S, et al. Efficacy of a multiplex paclitaxel emission stent using a Pluronic ${ }^{\circ}$ mixture membrane versus a covered metal stent in malignant biliary obstruction: a prospective randomized comparative study. Gut Liver 2017;11:567-573.

8. Song TJ, Lee SS, Yun SC, et al. Paclitaxel-eluting covered metal stents versus covered metal stents for distal malignant biliary obstruction: a prospective comparative pilot study. Gastrointest Endosc 2011;73:727733.

9. Suk KT, Kim JW, Kim HS, et al. Human application of a metallic stent covered with a paclitaxel-incorporated membrane for malignant biliary obstruction: multicenter pilot study. Gastrointest Endosc 2007;66:798803.

10. Kim DH, Jeong YI, Chung CW, et al. Preclinical evaluation of sorafenib-eluting stent for suppression of human cholangiocarcinoma cells. Int J Nanomedicine 2013;8:1697-1711.

11. Kwak TW, Lee HL, Song YH, et al. Vorinostat-eluting poly(DL-lactideco-glycolide) nanofiber-coated stent for inhibition of cholangiocarcinoma cells. Int J Nanomedicine 2017;12:7669-7680.

12. Sharaiha RZ, Khan MA, Kamal F, et al. Efficacy and safety of EUS-guided biliary drainage in comparison with percutaneous biliary drainage when ERCP fails: a systematic review and meta-analysis. Gastrointest Endosc 2017;85:904-914.

13. Lee TH, Choi JH, Park DH, et al. Similar efficacies of endoscopic ultrasound-guided transmural and percutaneous drainage for malignant distal biliary obstruction. Clin Gastroenterol Hepatol 2016;14:1011-1019. e3.

14. Park JK, Woo YS, Noh DH, et al. Efficacy of EUS-guided and ER$\mathrm{CP}$-guided biliary drainage for malignant biliary obstruction: prospective randomized controlled study. Gastrointest Endosc 2018;88:277-282.

15. Paik WH, Lee TH, Park DH, et al. EUS-guided biliary drainage versus ERCP for the primary palliation of malignant biliary obstruction: a multicenter randomized clinical trial. Am J Gastroenterol 2018;113:987997.

16. Bang JY, Navaneethan U, Hasan M, Hawes R, Varadarajulu S. Stent placement by EUS or ERCP for primary biliary decompression in pancreatic cancer: a randomized trial (with videos). Gastrointest Endosc 2018;88:9-17.
17. ASGE Technology Committee, Navaneethan U, Thosani N, et al. Radiofrequency ablation devices. VideoGIE 2017;2:252-259.

18. Steel AW, Postgate AJ, Khorsandi S, et al. Endoscopically applied radiofrequency ablation appears to be safe in the treatment of malignant biliary obstruction. Gastrointest Endosc 2011;73:149-153.

19. Figueroa-Barojas P, Bakhru MR, Habib NA, et al. Safety and efficacy of radiofrequency ablation in the management of unresectable bile duct and pancreatic cancer: a novel palliation technique. J Oncol 2013;2013:910897.

20. Dolak W, Schreiber F, Schwaighofer H, et al. Endoscopic radiofrequency ablation for malignant biliary obstruction: a nationwide retrospective study of 84 consecutive applications. Surg Endosc 2014;28:854-860.

21. Sharaiha RZ, Natov N, Glockenberg KS, Widmer J, Gaidhane M, Kahaleh M. Comparison of metal stenting with radiofrequency ablation versus stenting alone for treating malignant biliary strictures: is there an added benefit? Dig Dis Sci 2014;59:3099-3102.

22. Kallis Y, Phillips N, Steel A, et al. Analysis of endoscopic radiofrequency ablation of biliary malignant strictures in pancreatic cancer suggests potential survival benefit. Dig Dis Sci 2015;60:3449-3455.

23. Liang H, Peng Z, Cao L, Qian S, Shao Z. Metal stenting with or without endobiliary radiofrequency ablation for unresectable extrahepatic cholangiocarcinoma. J Cancer Ther 2015;6:981-992.

24. Hu B, Gao DJ, Zhang X, Zhang YC. Endobiliary radiofrequency ablation improve overall survival of cholangiocarcinoma: a multi-center randomized control study. Gastrointest Endosc 2016;83:5 Suppl:AB126.

25. Laquière $A$, Boustière $C$, Leblanc $S$, Penaranda G, Désilets E, Prat F. Safety and feasibility of endoscopic biliary radiofrequency ablation treatment of extrahepatic cholangiocarcinoma. Surg Endosc 2016;30:1242-1248.

26. Wang F, Li Q, Zhang X, et al. Endoscopic radiofrequency ablation for malignant biliary strictures. Exp Ther Med 2016;11:2484-2488.

27. Sofi AA, Khan MA, Das A, et al. Radiofrequency ablation combined with biliary stent placement versus stent placement alone for malignant biliary strictures: a systematic review and meta-analysis. Gastrointest Endosc 2018;87:944-951.el.

28. Yang J, Wang J, Zhou H, et al. Efficacy and safety of endoscopic radiofrequency ablation for unresectable extrahepatic cholangiocarcinoma: a randomized trial. Endoscopy 2018;50:751-760.

29. Park DH, Lee SS, Park SE, et al. Randomised phase II trial of photodynamic therapy plus oral fluoropyrimidine, $\mathrm{S}-1$, versus photodynamic therapy alone for unresectable hilar cholangiocarcinoma. Eur J Cancer 2014;50:1259-1268.

30. Cheon YK, Lee TY, Lee SM, Yoon JY, Shim CS. Longterm outcome of photodynamic therapy compared with biliary stenting alone in patients with advanced hilar cholangiocarcinoma. HPB (Oxford) 2012;14:185193.

31. Kahaleh M, Mishra R, Shami VM, et al. Unresectable cholangiocarcinoma: comparison of survival in biliary stenting alone versus stenting with photodynamic therapy. Clin Gastroenterol Hepatol 2008;6:290-297.

32. Ortner ME, Caca K, Berr F, et al. Successful photodynamic therapy for nonresectable cholangiocarcinoma: a randomized prospective study. Gastroenterology 2003;125:1355-1363.

33. Moole H, Tathireddy H, Dharmapuri S, et al. Success of photodynamic therapy in palliating patients with nonresectable cholangiocarcinoma: a systematic review and meta-analysis. World J Gastroenterol 2017;23:1278-1288.

34. Pereira SP, Jitlal M, Duggan M, et al. PHOTOSTENT-02: porfimer sodium photodynamic therapy plus stenting versus stenting alone in patients with locally advanced or metastatic biliary tract cancer. ESMO Open 2018;3:e000379.

35. Strand DS, Cosgrove ND, Patrie JT, et al. ERCP-directed radiofrequency ablation and photodynamic therapy are associated with comparable survival in the treatment of unresectable cholangiocarcinoma. Gastrointest Endosc 2014;80:794-804.

36. Arcidiacono PG, Carrara S, Reni M, et al. Feasibility and safety of 
EUS-guided cryothermal ablation in patients with locally advanced pancreatic cancer. Gastrointest Endosc 2012;76:1142-1151.

37. Suarez AL, Coté GA, Elmunzer BJ. Adjunctive radiofrequency ablation for the endoscopic treatment of ampullary lesions with intraductal extension (with video). Endosc Int Open 2016;4:E748-E751.

38. Song TJ, Seo DW, Lakhtakia $S$, et al. Initial experience of EUS-guided radiofrequency ablation of unresectable pancreatic cancer. Gastrointest Endosc 2016;83:440-443.

39. Rustagi $\mathrm{T}$, Irani S, Reddy DN, et al. Radiofrequency ablation for intraductal extension of ampullary neoplasms. Gastrointest Endosc 2017;86:170-176.

40. Rao B, Garg M, Singh S, Gulati A, Thakkar S. Successful use of radiofrequency ablation for the management of a recurrent ampullary adenoma with intraductal extension. VideoGIE 2018;3:94-96.

41. Scopelliti F, Pea A, Conigliaro R, et al. Technique, safety, and feasibility of EUS-guided radiofrequency ablation in unresectable pancreatic cancer. Surg Endosc 2018 May 15 [Epub]. https://doi.org/10.1007/s00464018-6217-x

42. Crinò SF, D’Onofrio M, Bernardoni L, et al. EUS-guided radiofrequency ablation (EUS-RFA) of solid pancreatic neoplasm using an 18-gauge needle electrode: feasibility, safety, and technical success. J Gastrointestin Liver Dis 2018;27:67-72.

43. Moyer MT, Sharzehi S, Mathew A, et al. The safety and efficacy of an alcohol-free pancreatic cyst ablation protocol. Gastroenterology 2017;153:1295-1303.

44. Choi JH, Seo DW, Song TJ, et al. Long-term outcomes after endoscopic ultrasound-guided ablation of pancreatic cysts. Endoscopy 2017;49:866873.

45. Choi JH, Seo DW, Song TJ, et al. Endoscopic ultrasound-guided radiofrequency ablation for management of benign solid pancreatic tumors. Endoscopy 2018;50:1099-1104.

46. Spiliotis JD, Datsis AC, Michalopoulos NV, et al. Radiofrequency ablation combined with palliative surgery may prolong survival of patients with advanced cancer of the pancreas. Langenbecks Arch Surg 2007;392:55-60.

47. Girelli R, Frigerio I, Salvia R, Barbi E, Tinazzi Martini P, Bassi C. Feasibility and safety of radiofrequency ablation for locally advanced pancreatic cancer. Br J Surg 2010;97:220-225.

48. Goldberg SN, Mallery S, Gazelle GS, Brugge WR. EUS-guided radiofrequency ablation in the pancreas: results in a porcine model. Gastrointest Endosc 1999;50:392-401.

49. Carrara S, Arcidiacono PG, Albarello L, et al. Endoscopic ultrasound-guided application of a new hybrid cryotherm probe in porcine pancreas: a preliminary study. Endoscopy 2008;40:321-326.

50. Petrone MC, Arcidiacono PG, Carrara S, et al. US-guided application of a new hybrid probe in human pancreatic adenocarcinoma: an ex vivo study. Gastrointest Endosc 2010;71:1294-1297.

51. Di Matteo FM, Saccomandi P, Martino M, et al. Feasibility of EUS-guided Nd:YAG laser ablation of unresectable pancreatic adenocarcinoma. Gastrointest Endosc 2018;88:168-174.e1.

52. Di Matteo F, Martino M, Rea R, et al. US-guided application of Nd:YAG laser in porcine pancreatic tissue: an ex vivo study and numerical simulation. Gastrointest Endosc 2013;78:750-755.

53. Di Matteo F, Martino M, Rea R, et al. EUS-guided Nd:YAG laser ablation of normal pancreatic tissue: a pilot study in a pig model. Gastrointest Endosc 2010;72:358-363.

54. Jiang T, Deng Z, Li J, Tian G. Pancreatic cancer: does it work if EUS and laser ablation get married? Endosc Ultrasound 2018;7:207-209.

55. Bang JY, Sutton B, Hawes RH, Varadarajulu S. EUS-guided celiac ganglion radiofrequency ablation versus celiac plexus neurolysis for palliation of pain in pancreatic cancer: a randomized controlled trial (with videos). Gastrointest Endosc 2019;89:58-66.e3.

56. Jin ZD, Wang L, Li Z. Endoscopic ultrasound-guided celiac ganglion radiofrequency ablation for pain control in pancreatic carcinoma. Dig Endosc 2015;27:163-164.
57. Nishimura M, Matsukawa M, Fujii Y, et al. Effects of EUS-guided intratumoral injection of oligonucleotide STNM01 on tumor growth, histology, and overall survival in patients with unresectable pancreatic cancer. Gastrointest Endosc 2018;87:1126-1131.

58. Hirooka Y, Kasuya H, Ishikawa T, et al. A phase I clinical trial of EUS-guided intratumoral injection of the oncolytic virus, HF10 for unresectable locally advanced pancreatic cancer. BMC Cancer 2018;18:596.

59. Levy MJ, Alberts SR, Bamlet WR, et al. EUS-guided fine-needle injection of gemcitabine for locally advanced and metastatic pancreatic cancer. Gastrointest Endosc 2017;86:161-169.

60. Hecht JR, Bedford R, Abbruzzese JL, et al. A phase I/II trial of intratumoral endoscopic ultrasound injection of ONYX-015 with intravenous gemcitabine in unresectable pancreatic carcinoma. Clin Cancer Res 2003;9:555-561.

61. Herman JM, Wild AT, Wang H, et al. Randomized phase III multi-institutional study of TNFerade biologic with fluorouracil and radiotherapy for locally advanced pancreatic cancer: final results. J Clin Oncol 2013;31:886-894.

62. Khashab MA, Kim KJ, Tryggestad EJ, et al. Comparative analysis of traditional and coiled fiducials implanted during EUS for pancreatic cancer patients receiving stereotactic body radiation therapy. Gastrointest Endosc 2012;76:962-971.

63. Ammar T, Coté GA, Creach KM, Kohlmeier C, Parikh PJ, Azar RR. Fiducial placement for stereotactic radiation by using EUS: feasibility when using a marker compatible with a standard 22-gauge needle. Gastrointest Endosc 2010;71:630-633.

64. Sanders MK, Moser AJ, Khalid A, et al. EUS-guided fiducial placement for stereotactic body radiotherapy in locally advanced and recurrent pancreatic cancer. Gastrointest Endosc 2010;71:1178-1184.

65. Dhadham GC, Hoffe S, Harris CL, Klapman JB. Endoscopic ultrasound-guided fiducial marker placement for image-guided radiation therapy without fluoroscopy: safety and technical feasibility. Endosc Int Open 2016;4:E378-E382.

66. Draganov PV, Chavalitdhamrong D, Wagh MS. Evaluation of a new endoscopic ultrasound-guided multi-fiducial delivery system: a prospective non-survival study in a live porcine model. Dig Endosc 2013;25:615621.

67. Zheng B, Wang X, Ma B, Tian J, Jiang L, Yang K. Endoscopic stenting versus gastrojejunostomy for palliation of malignant gastric outlet obstruction. Dig Endosc 2012;24:71-78.

68. Jeurnink SM, Steyerberg EW, van Hooft JE, et al. Surgical gastrojejunostomy or endoscopic stent placement for the palliation of malignant gastric outlet obstruction (SUSTENT study): a multicenter randomized trial. Gastrointest Endosc 2010;71:490-499.

69. Mehta S, Hindmarsh A, Cheong E, et al. Prospective randomized trial of laparoscopic gastrojejunostomy versus duodenal stenting for malignant gastric outflow obstruction. Surg Endosc 2006;20:239-242.

70. Khashab MA, Kumbhari V, Grimm IS, et al. EUS-guided gastroenterostomy: the first U.S. clinical experience (with video). Gastrointest Endosc 2015;82:932-938.

71. Itoi T, Itokawa F, Uraoka T, et al. Novel EUS-guided gastrojejunostomy technique using a new double-balloon enteric tube and lumen-apposing metal stent (with videos). Gastrointest Endosc 2013;78:934-939.

72. Itoi T, Ishii K, Ikeuchi N, et al. Prospective evaluation of endoscopic ultrasonography-guided double-balloon-occluded gastrojejunostomy bypass (EPASS) for malignant gastric outlet obstruction. Gut 2016;65:193195.

73. Perez-Miranda M, Tyberg A, Poletto D, et al. EUS-guided gastrojejunostomy versus laparoscopic gastrojejunostomy: an international collaborative study. J Clin Gastroenterol 2017;51:896-899.

74. Khashab MA, Bukhari M, Baron TH, et al. International multicenter comparative trial of endoscopic ultrasonography-guided gastroenterostomy versus surgical gastrojejunostomy for the treatment of malignant gastric outlet obstruction. Endosc Int Open 2017;5:E275-E281.

75. Chen YI, Itoi T, Baron TH, et al. EUS-guided gastroenterostomy is 


\section{$C_{\text {cunical ENoOSCOPY }}$}

comparable to enteral stenting with fewer re-interventions in malignant gastric outlet obstruction. Surg Endosc 2017;31:2946-2952.

76. Itoi T, Baron TH, Khashab MA, et al. Technical review of endoscopic ultrasonography-guided gastroenterostomy in 2017. Dig Endosc
2017;29:495-502.

77. Chen YI, Kunda R, Storm AC, et al. EUS-guided gastroenterostomy: a multicenter study comparing the direct and balloon-assisted techniques. Gastrointest Endosc 2018;87:1215-1221 